\title{
MALAPARI (Pongamia Pinnata (L.) Piere) GROWTH ON THREE PLANTING PATTERNS WITH Trichoderma AND Mycorrhizae APPLICATION
}

\author{
Aditya Hani*, Benyamin Dendang, and Levina. A. G. Pieter \\ Institute for Research and Development on Agroforestry Technology \\ Jl. Ciamis-Banjar Km 4 Po Box 5 Ciamis
}

Received: 29 March 2021, Revised: 12 October 2021, Accepted: 18 October 2021

\begin{abstract}
MALAPARI (Pongamia pinnata (L.) Piere) GROWTH ON THREE PLANTING PATTERNS WITH Trichoderma AND Mycorrbizae APPLICATION. Malapari (Pongamia pinnata) is a potential plant for biodiesel and has the ability to grow on marginal land. Malapari cultivation has not yet been carried out due to low economic value. Agroforestry crop patterns are expected to provide intermediate results so that people would be interested in planting malapari. Planting on coastal land requires the right technology to produce optimal growth. This study aims to determine the effect of malapari cropping patterns and evaluate biological fertilizer application in the seedling phase after planting in the field. The research uses a split plot design (Split Plot Design) with the main factors that are the pattern of malapari planting and sub-plots that are the type of application of biofertilizer. The results obtained from the study showed that the interaction of cropping pattern treatment and biofertilizer application did not give significant growth to malapari; the combination of the application of organic manure, Trichoderma spp. and mycorrhiza bio-fertilizers in the nursery yielded the largest malapari diameter growth after planting in the field at the age of 3 years.
\end{abstract}

Keywords: Agroforestry, malapari, biofertilizer, community perception

PERTUMBUHAN MALAPARI (Pongamia pinnata (L.) Piere) PADA TIGA POLA TANAMAN DENGAN APLIKASI Trichoderma DAN Mikoriza. Malapari (Pongamia pinnata) merupakan jenis pohon yang berpotensi dikembangkan untuk pembuatan biodiesel dan untuk tumbuh pada laban kritis. Tanaman malapari dianggap belum memiliki nilai ekonomi dan pasar yang jelas, sehingga masyarakat tidak tertarik untuk membudidayakannya. Pola tanaman agroforestri diharapkan dapat memberi hasil antara, sehingga masyarakat tertarik menanam malapari. Penanaman pada lahan pantai memerlukan teknologi yang tepat agar menghasilkan pertumbuhan yang optimal. Penelitian ini bertujuan untuk mengetabui pengarub pola tanam malapari dan mengevaluasi pemberian pupuk. hayati pada fase bibit setelah ditanam dilapangan. Penelitian menggunakan rancangan petak terbagi (Split Plot Design) dengan faktor utama yaitu pola tanam malapari dan anak petak berupa jenis aplikasi pupuk. hayati. Hasil penelitian menunjukan babwa interaksi perlakuan pola tanam dan pemberian pupuk bayati tidak memberikan perbedaan pertumbuhan yang nyata. Faktor tunggal perlakuan pemberian pupuk hayati di persemaian menghasilkan perbedaan pertumbuban di lapangan. Pemberian kompos dan pupuk bayati trichoderma dan mikoriza sejak di persemaian menghasilkan pertumbuhan diameter malapari terbesar setelah ditanam dilapangan bingga umur 3 tabun.

Kata kunci: Agroforestri, malapari, pupuk, hayati, persepsi masyarakat

*Corresponding author: adityahani@gmail.com 


\section{INTRODUCTION}

Malapari (Pongamia pinnata) is a potential species that can be developed as a biofuel producer. The oil content in malapari seeds ranges from 17-42\% (Febritasari, Arpiwi, \& Wahyuni, 2016). Biodiesel has the advantage of being non-toxic, renewable and naturally biodegradable (Dwitama, Nazib, \& Sitepu, 2016). Unlike palm oil or soybean oil, malapari oil is inedible. Therefore, it would be easier to maintain the yield (Simpen, Negara, \& Puspawati, 2018). Malapari biodiesel has similar characteristic with the conventional diesel fuel (Nicholas, Venkatakrishna, Joy, \& Mariadhas, 2019). Biodiesel reduces the possibilities of acid rain and considered as climate-neutral because it does not contain sulphur (Uharani, Naik, \& Manjunatha, 2019). Moreover, malapari biodiesel emits lower emission of $\mathrm{HC}, \mathrm{CO}$, NOx gas, and smoke (Nicholas et al., 2019). In Indonesia, the production of malapari for biodiesel is still limited due the unpopularity of the plants.

Until now, the existence of malapari plants still relies on its natural population, mostly in coastal forests. Malapari planting in coastal areas needs to overcome extreme climatic conditions, low soil fertility and high salinity. Salinity stress can cause a nutrient imbalance in plants and damage the osmosis balance of plant cells (Naik, Mishra, Srichandan, Singh, \& Sarangi, 2019). Moreover, the natural population of malapari in Java is mostly in a threatening condition due to abrasion, which causes fallen trees and loss of land where it grows (Jayusman, 2018). The loss of native coastal forest vegetation such as malapari was also caused due to logging for human settlements and invasive species due to human intervention (Priosambodo, 2018). Therefore, malapari cultivation needs to be done immediately to increase the population in the nature.

Agroforestry in the tropics has a very important role for the community. Agroforestry can increase farmers' adaptation to various situations, resilience of local farming systems and provide more diverse sources of livelihood
(Jha, Kaechele, \& Sieber, 2021). In dry areas, the presence of shade trees can maintain, protect plant growth from too high light intensity and improve yield quality, for example increasing protein content in food crops (Hani, Indrajaya, Suryanto, \& Budiadi, 2016). Agroforestry aims to make crop cultivation systems more affordable and compatible with low input costs and ensure more sustainable soil management, protect land resources and provide environmental services (Bado, Whitbread, \& Manzo, 2021).

The arbuscular mycorrhizal fungi ( $A M$ fungi) plays a significant role in the ecosystem. AM fungi increases the nutrient uptake, strengthens plants adaptability and promotes plants resistance to stress (Kapulnik, Tsros, Zipori, Hazanovsky, \& Wininger, 2010, Begum et al., 2019). Hyphal network of $A M$ fungi and plant roots enhances the root's accessibility to a larger area which improves plant growth (Bowles, Barrios-Massias, Charlisle, Cavagnaro, \& Jackson, 2016). On the tropical trees, $A M$ fungi prevents the foliar damage's negative effect on seedling (Bachelot, Uriarte, McGuire, Thomson, \& Zimmerman, 2016), influences the seedlings' whole-plant respiration (Fahey, Winter, Slot, \& Kitijima, 2016), improve growth, increase $\mathrm{P}$ uptake, leaf greenness index of Albizia chinensis and malapari seedlings (Budi, Arty, Wasis, Wibowo, \& Sukendro, 2020). According to Agus, Primananda, Faridah, Wulandari, and Lestari (2019), the application of $A M$ fungi improves the growth of malapari seedling and enhance the chemical soil property on the post mining areas. Agroforestry system is a land management system where trees and shrubs or crops are grown around or among the pastureland. Agroforestry practices help improving the environmental quality, while supporting agricultural productions especially on the marginal land. Community tends to refuse planting unpopular tree species such as malapari since it takes a long time to produce yield. Thus, agroforestry could become an answer for this. On the implementation, agroforestry needs some input regarding technology and dissemination of simple 
technology such as biofertilizer and cropping pattern for increasing productivity, increased awareness and sustainability for farmers.

Trichoderma are endophytic plant symbionts that perform as plant stimulation growth, inhibit the negative effects of plant's disease, and improve the seed germination on tomato and pepper (Montesinos, Dianez, MorenoGavira, Gea, \& Santos, 2020; Ahmad et al., 2015). Trichoderma form a colony on the rhizosphere which is antagonistic towards soil borne pathogens. Kashyap, Rai, Srivastava, and Kumar (2017) reported that Trichoderma could enhance nutrient uptake, improve photosynthetic efficiency, facilitate plants for adaptation, and mitigate climate change's adverse effect. The use of mycorrbizal fungi 10 $\mathrm{g}+$ Trichoderma spp. $10 \mathrm{~g}+$ organic manure produces Nyamplung (Calophyllum inophyllum) seeds with greater biomass than without the treatment of biological fertilizers (Dendang \& Hani, 2018). The inoculation of combination between Trichoderma and $A M$ fungi has been widely used since both of the bio-fertilizers are inexpensive and accessible. Poveda, Hermosa, Monte, and Nicolas (2019) found that Trichoderma accommodate the $A M$ fungi to inoculate the root plants of Brassicaceae family and improve the productivity. Moreover, Dehariya, Shukila, Ganaie, and Vyas (2015) found that the combination between Trichoderma and $A M$ fungi gave maximum growth and wilt protection from Fusarium. The positive effect of applying biological fertilizers to date has been limited to the seedlings in the nursery. This study aimed to determine the effect of malapari cropping patterns and biofertilizer application in the field in community's coastal land area.

\section{MATERIALS AND METHODS}

\section{A. Site Description}

The research was conducted from 2016 to 2019 in Patutrejo Village (7 $50^{\prime} 46.1^{\prime \prime}$ 'S, 10953'55.4’E), Purworejo Regency, Central Java (Figure 1). The research location was in a coastal area within $\pm 500 \mathrm{~m}$ of coastlines. The site soil was checked at the Jenderal Soedirman

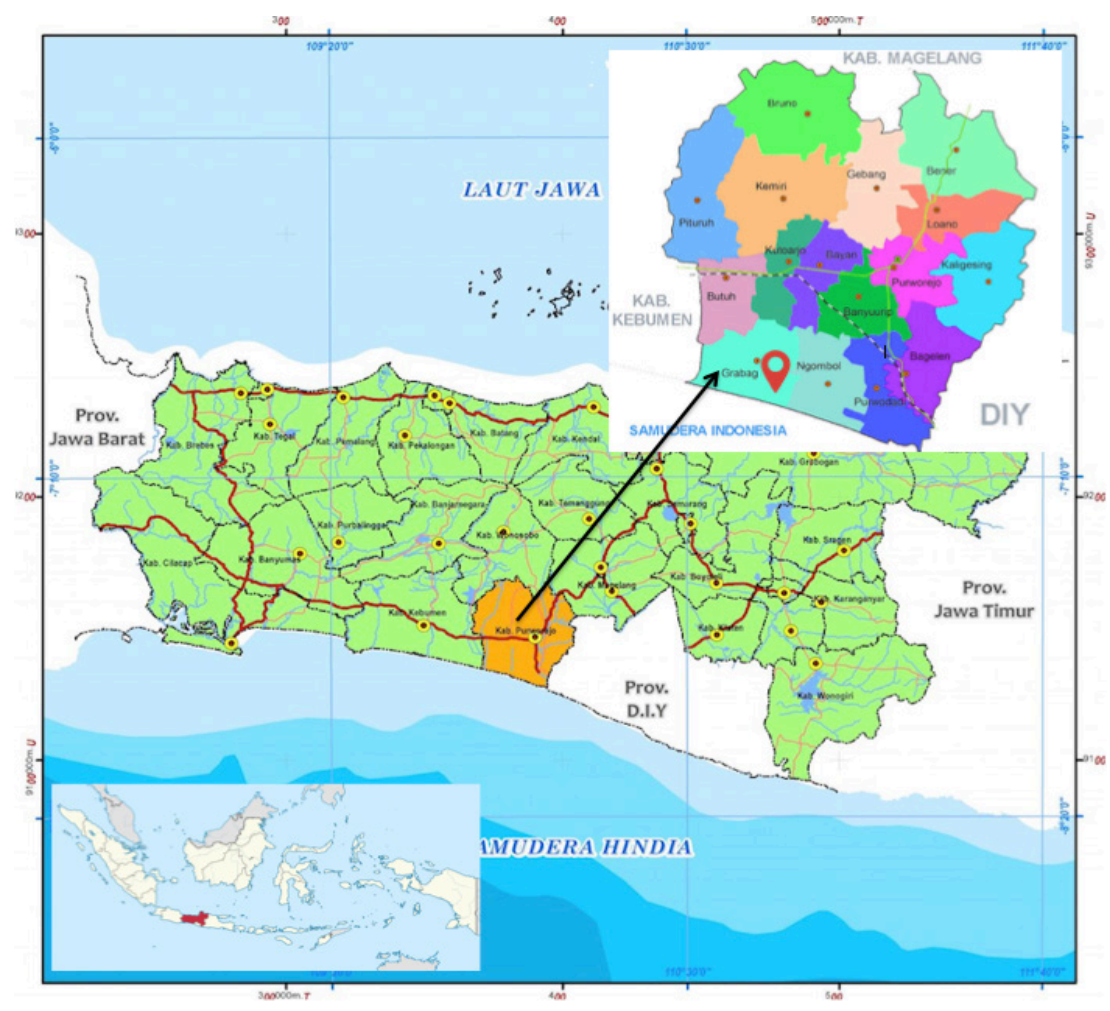

Figure 1. Site location 
Table 1. Soil analysis at the study site

\begin{tabular}{|c|c|c|c|c|c|}
\hline \multirow{2}{*}{ No. } & \multirow{2}{*}{ Parameter } & \multicolumn{3}{|c|}{ Results } & \multirow{2}{*}{ Criteria $^{*}$} \\
\hline & & Block 1 & Block 2 & Block 3 & \\
\hline 1. & C-Organik (\%) & 0.683 & 0.717 & 0.895 & $<1$ very low \\
\hline 2. & N-total $(\%)$ & 0.079 & 0.086 & 0.104 & $<0.1$ very low \\
\hline 3. & $\mathrm{C} / \mathrm{N}$ ratio & 8.65 & 8.34 & 8.61 & $5-10$ low \\
\hline 4. & $\mathrm{pH}$ & 5.66 & 5.72 & 6.15 & $5.5-6.5$ slightly acid \\
\hline 5. & $\mathrm{P}_{2} \mathrm{O}_{5}$ total $(\%)$ & 0.292 & 0.300 & 0.286 & $>0.06$ very high \\
\hline 6. & $\mathrm{~K}_{2} \mathrm{O}$ total $(\%)$ & 0.037 & 0.038 & 0.039 & $0.02-0.04$ intermediate \\
\hline 7. & $\mathrm{~N}^{-\mathrm{NH}_{4}}(\mathrm{ppm})$ & 39.248 & 24.442 & 41.856 & \\
\hline 8. & Available $\mathrm{P}_{2} \mathrm{O}_{2}(\mathrm{ppm})$ & 27.577 & 23.425 & 10.639 & $>20$ very high \\
\hline 9. & Available $\mathrm{K}_{2} \mathrm{O}($ me $\%)$ & 0.082 & 0.113 & 0.086 & $0.1-0.3$ low \\
\hline 10. & Organic matter (\%) & 1.178 & 1.236 & 1.543 & \\
\hline \multirow[t]{4}{*}{11.} & Texture & & & & \multirow[t]{4}{*}{ sand } \\
\hline & Sand $(\%)$ & 93.15 & 92.40 & 90.35 & \\
\hline & Loam (\%) & 3.56 & 4.45 & 4.98 & \\
\hline & Clay (\%) & 3.29 & 3.15 & 4.67 & \\
\hline
\end{tabular}

* Source: Hardjowigeno (1987)

University's soil laboratorium in Purwokerto, Central Java. The soil analysis is shown in Table 1. The community has used the land for agriculture. The research about perception and attitude of the community was conducted in August-October 2018.

\section{B. Seed and Media Preparation}

Malapari ripe fruit was collected from Batukaras, Pangandaran, West Java. The seeds were extracted from the fruit then planted in $10 x 15 \mathrm{~cm}$ polybags, one seed per polybag. Each polybag was filled with a mixture of topsoil, manure and sand (1:1:1). The polybag was placed under shading net and watered daily. The crop seeds were bought from a local agricultural supply store. The crop seeds were spread on the tray and transplanted in the field after four true leaves emerged.

\section{Biofertilizer Preparation}

The commercialized AM fungiand Trichoderma spp. $($ Trademark $=$ Greemi-G) were used in this study to determine the effect of biofertilizer. Greemi-G contains T. Pseudokoningii DT 39, T.harzianum DT 38, T. hariianum DT 10, T. harzianum DT 29, and is produced in the form of granules They were bought from an agricultural supply store. The six month old malapari seedlings were inoculated with $A M$ fungi and/or Trichoderma. The dosage was 10 gram/each seedling according to the design experiment.

\section{Design Experiment}

This research was carried out with a splitplot design. The main factor was the malapari cropping pattern, and the split-plot factor was the biofertilizer application. The main factor consisted of: a) malapari monoculture, b) malapari + annual crops, c) malapari + papaya. There were 3 replications for the cropping pattern. The split-plot factors consisted of: a) soil: organic manure (1:1) + AM Fungi (10 g); b) soil : organic manure (1:1) + Trichoderma; c) soil (control), d) soil : organic manure (1:1); e) soil : organic manure $(1: 1)+$ mycorrbiza $(10 \mathrm{~g})+$ trichoderma $(10 \mathrm{~g})$; using five plants per factor. The total number of observed malapari plants were 225 plants.

Malapari plant spacing was $4 \mathrm{~m} \times 4 \mathrm{~m}$, while the malapari and annual crop pattern planting was in the middle aisle. Before planting into the field, $8 \mathrm{~kg}$ of manure was applied to each planting hole. Maintenance activities were: weeding three times per year and fertilizing 
using a mixture of urea + Tsp $100 \mathrm{~g}$ per plant at 4 and 8 months after planting.

\section{E. Growth and Yield Measurement}

The parameters observed for malapari growth were survival percent, plant height and diameter. These parameters were measured every six month. Yield measurement of the crop were done at each harvesting time. Anual crop production was calculated by weighing all harvests in a $400 \mathrm{~m}^{2}$ observation plot.

\section{F. Analysis}

Data were analyzed using SPSS version 26. One-way ANOVA examined effects on treatments on the growth parameter. Differences between treatments were determined using Duncan's tests.

\section{RESULT AND DISCUSSION}

\section{A. Malapari (Pongamia pinnata (L.) Piere) Growth}

The interaction treatment between cropping patterns and the application of biological fertilizers (Trichoderma and $A M$ fungi) did not significantly affect 3 years old plants (Table $2)$. The results of the analysis of variance showed that the single factor in the form of bio fertilizers that gave a real difference to malapari was the diameter growth between treatments, but not in the height. This might be because the increase in the diameter occurs to facilitate the nutrients and photosynthate transportation process that is higher from the biofertilizer, while the plant spacing is adequate. Therefore, the growth in plant diameter became significant (Table 2).
This result showed that Trichoderma and $A M$ fungi application could be combined and interact simultaneously. Interactions between mycorrbizae and trichoderma can accelerate plant growth, also found in palm seedlings after ten months and can prevent the emergence of stem rot disease (Simanjuntak, Fahridayanti, \& Susanto, 2013). The interaction of mycorrbiza and Trichoderma keep plants healthy (Allfizar, Marlina, \& Hasanah, 2011). Mycorrhiza plays a role in improving soil physical properties by producing glomalin glycoprotein compounds and organic acids that fertilize the soil and increases the P availability in the soil (Ginting, Dewi, \& Yuliani, 2018; Singh, Singh, \& Tripathi, 2013). On the other hand, Trichoderma increases plant resistance to disease attack in the soil by suppressing the development of other harmful microbes (Ji, Liu, Liu, \& Wang, 2019). This might answer why there were no plant diseases at the site locations.

The synergy between organic manure, $A M$ fungi, and Trichoderma positively influenced the growth in diameter, because biofertilizer providing nutrients for plants. The interaction of Trichoderma and mycorrbizae increases the availability of $\mathrm{P}$ and $\mathrm{K}$ elements in the soil which are essential (Santi, Defiani, \& Proborini, 2019). The presence of soil microbes (fungi and bacteria) increase soil fertility in coastal areas with high salinity (Zhang, Chong, Rui, \& Lijie, 2019). Improvement of soil microbiology after planting in high salinity soils will increase availability of phosphorus and alkaline phosphates compared to unplanted coastal land (Shao, Zhao, Liu, Long, \& Rengel, n.d.). Concurrent inoculation between Trichoderma

Table 2. Duncan's test: effects of bio-fertilizer application on malapari growth

\begin{tabular}{ll}
\hline Treatment & Diameter $\mathbf{( c m )}$ \\
\hline Soil+Organic manure+Trichoderma+Mycorrbizae & $5.70 \mathrm{a}$ \\
Soil+Organic manure+Trichoderma & $5.39 \mathrm{ab}$ \\
Soil (control) & $5.17 \mathrm{ab}$ \\
Soil+Organic manure+Mycorrbizae & $4.45 \mathrm{bc}$ \\
Soil+Organic manure & $4.24 \quad \mathrm{c}$ \\
\hline
\end{tabular}


Table 3. Survival percentage of malapari plant

\begin{tabular}{lcccc}
\hline \multirow{2}{*}{ Biofertilizer } & \multicolumn{3}{c}{ Survival percentage (\%) } \\
\cline { 2 - 5 } & $\begin{array}{c}\text { Malapari+ } \\
\text { Papaya }\end{array}$ & $\begin{array}{c}\text { Malapari } \\
\text { Monoculture }\end{array}$ & $\begin{array}{c}\text { Malapari + } \\
\text { annual crop }\end{array}$ & Mean \\
\hline Soil & 100 & 100 & 100 & 100.00 \\
Soil+Organic manure & 100 & 100 & 100 & 100.00 \\
Soil+Organic manure+AMF+ & 80 & 100 & 80 & 86.67 \\
Trichoderma & & & 100 & 86.67 \\
Soil+Organicmanure+Trichoderma & 60 & 100 & 100 & 93.33 \\
Soil+Organic manure+AMF & 100 & 80 & 96 & \\
Mean & 88 & 96 & & \\
\hline
\end{tabular}
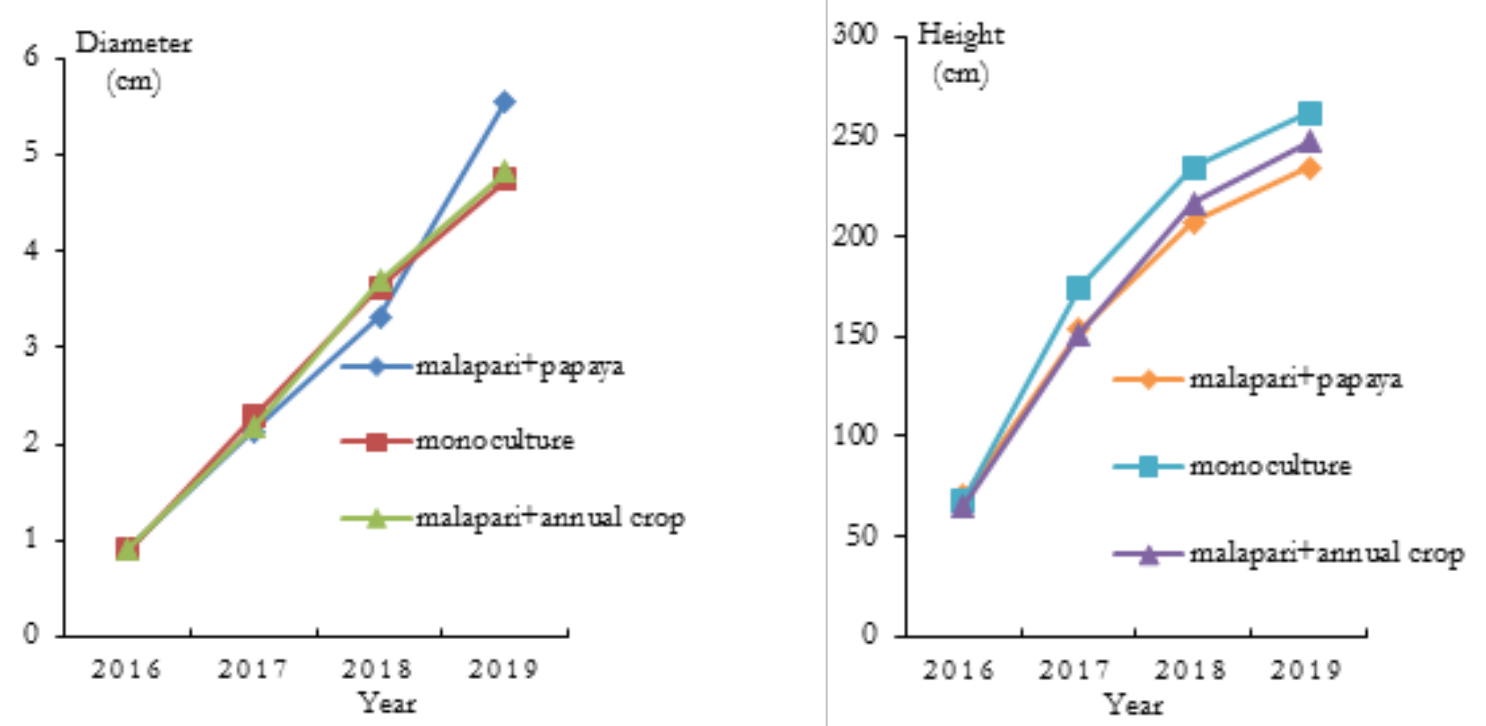

Figure 2. Total height and diameter of malapari in three planting patterns

and $A M$ fungi will divide the colonization area at the plant's root to strengthen the root system and plant strength when planted in the field (Talbi et al., 2016). With the good nutrient and the favor of the biofertilizer the plants had high survival percentage (Table 3).

The cropping pattern treatment did not give a significant difference to the growth of malapari. However, the malapari + papaya cropping pattern started to show a slight increase in the third year compared to other planting patterns (Figure 2). The diameter of a tree is generally influenced by soil fertility and growth space. Vast growth space will reduce competition with other plants to obtain nutrients. Papaya planted between malapari plants has a relatively wider distance than planting annual crops such as beans, chilli peppers, and corn. Thus, the competition at the root level is lower. Environmental factors play a role in tree growth at the age of 1-3 years compared to genetic factors(Susanto \& Baskorowati, 2018). Adequate nutrients in the soil will produce optimal growth. The higher the soil fertility, the greater the vegetation's growth (Rusdiana \& Lubis, 2012).

The different malapari agroforestry patterns provided almost similar yield, except for the watermelon in the second year (Table 4). The curly red chilli pepper had a better outcome 
on malapari agroforestry patterns. This might be because the red chili production in agroforestry pattern is not much different from monoculture chili production. Yields of annual crops, vegetables and fruits, were quite good at the study site although still lower than in monocultures. Lower agroforestry production is more due to the reduction in the annual crop cultivation sector than due to malapari plants' presence. Farmers at the study site have adapted to the environmental conditions of the coastal area. They make several extra efforts for adaptation, including guarding of coastal forest that functions as a windbreak, applying regular manure from livestock, and suitable species selection. The practice of regular manure application might make the soil more acidic. As another example, farmers in Senegal applying manure, planting trees for conservation, mulching and planting tolerant species (Thiam, Villamor, Kyei-Baffour, \& Matty, 2019). The yield of annual crops from the agroforestry patterns is presented in Table 4.

The application of organic material from seasonal plant debris and provision of manure will improve soil fertility in sandy areas. Organic matter will improve the physical properties and increase the clay content in sandy soils (Nganga et al., 2020). Agricultural cultivation will continuously reduce soil salinity, increase soil nutrient content and increase soil microorganism diversity (Xu et al., 2020). The cropping pattern can reduce soil salinity in coastal land to the highest level if the layered canopy vegetation is a mixture of trees, shrubs and grass (Xia, Ren, Zhang, Wang, \& Fang, 2019). The combination of suitable plant types, microbes that are resistant to stress conditions and the addition of organic matter are three factors to increase plant growth in extreme agroecosystem conditions (Vimal, Singh, Arora, \& Singh, 2017). Optimizing crop types through agroforestry patterns could increase the organic matter. An agroforestry pattern with a high multistrata and biomass header, in the long run, will improve the salinity of coastal land. According to Gresshoff et al. (2015), malapari starts flowering after three years and harvest of the first fruits can be done at four years. This was shown at the site, where the three-year-old plant was already producing fruit. The relatively fast production time is expected to increase the interest of the community in cultivating malapari. In addition, with the agroforestry pattern, community's income, both short and medium-term, can be feasible.

\section{CONCLUSION}

The interaction of cropping pattern treatment and biofertilizer application did not give significant growth to malapari. The growth of plant diameter is influenced by different treatments of a single factor, namely application of biofertilizer. Interactions between mycorrbizae and Trichoderma can accelerate plant growth.

\section{ACKNOWLEDGEMENT}

The author would like to thank the Patutrejo Village Government for providing land for the

Table 4. Annual crop production of malapari agroforestry patterns

\begin{tabular}{lccc}
\hline \multicolumn{1}{c}{ Planting pattern } & Area $\left(\mathbf{m}^{\mathbf{2}}\right)$ & Agroforestry (kg) & Monoculture (kg) \\
\hline Second-year & & 110 & 125 \\
Corn & 400 & 117 & 140 \\
Red chilli pepper & 400 & 180 & 350 \\
Watermelon & 400 & 350 & 330 \\
Third-year & & & \\
Curly red chilli pepper & 625 & & \\
\hline
\end{tabular}

Note: Papaya did not give a good yield 
research activities; the Agroforestry Research and Development Center for providing research funds and Encep Rachman who participated in providing input and contribution during research activities.

\section{REFERENCES}

Agus, C., Primananda, E., Faridah, E., Wulandari, D., \& Lestari, T. (2019). Role of arbuscular mycorrhizal fungi and Pongamia pinnata for revegetation of tropical open-pit coal mining soils. International Journal of Environmental Science and Technology, 16(7), 3365-3374.

Ahmad, P., Hashem, A., Abd-Allah, E. F., Alqarawi, A. A., John, R., Egamberdieva, D., \& Gucel, S. (2015). Role of Trichoderma harzianum in mitigating $\mathrm{NaCl}$ stress in Indian mustard (Brassica juncea L.) through antioxidative defense system. Frontier Plant Science, 14(October).

Allfizar, Marlina, \& Hasanah, N. (2011). Upaya pengendalian penyakit layu Fusarium oxysporum dengan pemanfaatan agen hayati cendawan FMA dan Trichoderma harzianum. Floratek, 6(8), 8-17.

Bachelot, B., Uriarte, M., McGuire, K. L., Thomson, J., \& Zimmerman, J. (2016). Arbuscular mycorrhizal fungal diversity and natural enemies promote coexistence of tropical tree species. Ecology, 98(3), 712-729.

Bado, B. V., Whitbread, A., \& Manzo, M. S. (2021). Improving agricultural productivity using agroforestry systems: Performance of millet, cowpea and ziziphus-based croping systems in West Africa Sahel. Agriculture, Ecosystems and Environment, 305(107175), 1-10.

Begum, N., Qin, C., Ahanger, M. A., Raza, S., Khan, M. I., Ashraf, M., ... Zhang, L. (2019). Role of arbuscular mycorrhizal fungi in plant growth regulation: Implications in abiotic stress tolerance. Frontier in Plant Science, 10(1068).

Bowles, T. M., Barrios-Massias, F. H., Charlisle, E. A., Cavagnaro, T. R., \& Jackson, L. E. (2016). Effects of arbuscular mycorrhizae on tomato yield, nutrient uptake, water relations, and soil carbon dynamics under deficit irrigation in field conditions. Science of The Total Environment, 566, 1223-1234.

Budi, S. W., Arty, B., Wasis, B., Wibowo, C., \& Sukendro, A. (2020). Influence of arbuscular mycorrhizal fungi and soil ameliorants on the mycorrhizal colonization, chlorophyll content, and performance growth of two tropical tree seedlings grown in soil media with high aluminum content. Malaysia Applied Biology, 49(1), 41-53.

Dehariya, K., Shukila, A., Ganaie, M. A., \& Vyas, D. (2015). Individual and interactive role of trichoderma and mycorrhizae in controlling wilt disease and growth reduction in Cajanus cajan caused by Fusarium udum. Phytopathology and Plant Protection, 48(1), 50-61.

Dendang, B., \& Hani, A. (2018). Peningkatan kualitas bibit nyamplung (Calophyllum inophyllum L.) dan malapari (Pongamia pinnata L.) dengan aplikai mikoriza dan Trichoderma spp. Jurnal Pemuliaan Pohon, 12(1), 75-84.

Dwitama, M. I., Nazib, M., \& Sitepu. (2016). Konversi minyak biji malapari (Pongamia pinnata L.) menjadi biodiesel melalui pemanfaatan katalis heterogen abu sekam padi termodifikasi Li. Jurnal Kimia, 10(2), 236-244.

Fahey, C., Winter, K., Slot, M., \& Kitijima, K. (2016). Influence of arbuscular mycorrhizal colonization on whole-plant respiration and thermal acclimation fo tropical tree seedlings. Ecology and Evolution, 6(3), 859-870.

Febritasari, F., Arpiwi, N., \& Wahyuni, I. G. A. S. (2016). Karakteristik dan analisis hubungan kekerabatan malapari (Pongamia pinnata (L.) Pierre) sebagai tanaman penghasil minyak di dua aksesi. Jurnal Metamorfosa, III(2), 74-81.

Ginting, A. E., Dewi, \& Yuliani, S. K. (2018). Pengaruh mikoriza vesikular dan Trichoderma harzianum pada pertumbuhan tanaman sawi hijau (Brassica juncea L.) di tanah liat dan tanah pasir. LenteraBio, 7(3), 231-235.

Gresshoff, P. M., Hayashi, S., Biswas, B., Mirzaei, S., Indrasumunar, A., Reid, D., ... Fergusona, B. J. (2015). The value of biodiversity in legume symbiotic nitrogen fixation and nodulation for biofuel and food production. Journal of Plant Physiology, 172, 128-136.

Hani, A., Indrajaya, Y., Suryanto, P., \& Budiadi. (2016). Dry land agroforestry practices in Menoreh Hills, Kulon Progo. Agrivita, 38(2), 193-203.

Hardjowigeno. (1987). Ilmu tanah. Yogyakarta: Mediyatama Sarana Perkasa.

Jayusman. (2018). Penetapan strategi pemuliaan untuk mendukung pengembangan malapari (Pongamia pinnata L.) sebagai penghasil biofuel. Proceeding Biology Education Conference, 15(1), 737-742. 
Jha, S., Kaechele, H., \& Sieber, S. (2021). Faktor influencing the adoption of agroforestry by smalholder farmer houehold in Tanzania: Case studies from Morogoro and Dodoma. Land Use Policy, 103(105308), 1-15.

Ji, S., Liu, Z., Liu, B., \& Wang, Y. (2019). Comparative analysis of biocontrol agent Trichoderma asperellum ACCC30536 transcriptome during its interaction with Populus davidiana $\mathrm{x} P$. alba var. pyramidalis. Microbiological Research, 227(126294), 1-10.

Kapulnik, Tsros, L., Zipori, I., Hazanovsky, M., \& Wininger, S. (2010). Effect of AMF application on growth, productivity and susceptibility to verticilium wilt of olives grown under desert conditions. Symbiosis, 52(2), 103-111.

Kashyap, P. L., Rai, P., Srivastava, A. K., \& Kumar., S. (2017). Trichoderma for climate resilient agriculture. World Journal of Microbiology and Biotechnology, 33(8), 155.

Montesinos, B. S., Dianez, F., Moreno-Gavira, A., Gea, F. J., \& Santos, M. (2020). Role of Trichoderma aggressivum, F. europaeum as plantgrowth promoter in horticulture. Agronomy, 10(7).

Naik, K., Mishra, S., Srichandan, H., Singh, P. K., \& Sarangi, P. K. (2019). Plant growth promoting microbes: Potential link to sustainable agriculture and environtment. Biocatalysus and Agricultural Biotechnology, 21(101326), 1-12.

Nganga, W. B., K, O. N., Macharia, M. J., Kiboi, N. M., Adamtey, N., \& Ngetich, K. F. (2020). Multi-influenceing-factors evaluation for organic-based soil fertility technologies outscaling in Upper Tana Cathment in Kenya. Scientific African, 7(e00231), 1-16.

Nicholas, T. A., Venkatakrishna, A., Joy, N., \& Mariadhas, A. (2019). Performance $n$ emission analysis on diesel engine fuelled with neat pongamia biodiesel. International Journal of Ambient Energy, (June), 1-7.

Poveda, J., Hermosa, R., Monte, E., \& Nicolas, C. (2019). Trichoderma harzianum favours the access of arbuscular mycorrhizal fungi to non-host Brassicaceae roots and increases plant productivity. Scientific Reports, 9(11650).

Priosambodo. (2018). Vegetasi hutan pantai Sabutung Sulawesi Selatan. Jurnal Ilmu Alam dan Lingkungan, 9(17), 19-30.

Rusdiana, O., \& Lubis, R. S. (2012). Pendugaan korelasi antara karakteristik tanah terhadap cadangan karbon (carbon stock) pada hutan sekunder. Jurnal Slvikultur Tropika, 3(1), 14 21.
Santi, W. P., Defiani, R. M., \& Proborini, M. W. (2019). Potensi inokulasi jamur Trichoderma viride dan Glomus sp. terhadap produktivitas Capsicum annum L. Jurnal Mikologi Indonesia, 3(2), 95-103.

Shao, T., Zhao, J., Liu, A., Long, X., \& Rengel, Z. (n.d.). Effects of soil physicochemical properties on microbial communities in different ecological niches in coastal area. Applied Soil Ecology, 150(103486), 1-9.

Simanjuntak, D., Fahridayanti, \& Susanto, A. (2013). Efikasi mikoriza dan Trichoderma sebagai pengendali penyakit busuk pangkal batang (Ganoderma) dan sebagai pemacu pertumbuhan di pembibitan kelapa sawit. Widyariset, 16(2), 233-242.

Simpen, I. N., Negara, I. M. S., \& Puspawati, N. M. (2018). The characterization of hetergeneous nanocatalyst of biohydroxyapatite-Lithium and its application for converiting malapari seed oil (Milletia pinnata L.) to biodiesel. Oriental Journal of Chemistry, 34(4), 18171823.

Singh, P., Singh, M., \& Tripathi, B. (2013). Glomalin: An arbuscular mycorrhizal fungal soil protein. Protoplasma, 250, 663-669.

Susanto, M., \& Baskorowati, L. (2018). Pengaruh genetik dan lingkungan terhadap pertumbuhan sengon (Falcataria molucanna) ras lahan Jawa. Bioeksperimen, 4(2), 35-41.

Talbi, Z., Chliyeh, M., Mouria, B., Asari, A. El, Aguil, F. A., Touhami, A. O., ... Douira, A. (2016). Effect of double inoculation with endomycorrhizae and Trichoderma harzanium on the growth of carob plants. International Journal of Advances Inpharmacy, Biology and Chemistry, 5(1), 44-58.

Thiam, S., Villamor, G. B., Kyei-Baffour, N., \& Matty, F. (2019). Soil salinity assessment and coping strategies in the coastal agricultural landscape in Djilor district, Senegal. Land Use Policy, 88(104191), 1-9.

Uharani, K. V., Naik, D., \& Manjunatha, R. L. (2019). Composition and advantages in agriculture : A review. Journal of Pharmacognosy and Phytochemistry, 8(3), 2181-2187.

Vimal, S. R., Singh, J. S., Arora, N. K., \& Singh, S. (2017). Soil-plant-microbe interaction in stressed agriculture management: A review. Pedosphere, 27(2), 177-192.

Xia, J. bao, Ren, J., Zhang, S., Wang, Y., \& Fang, Y. (2019). Forest and grass composite patterns improve the soil quality in the coastal salinealkali land of the Yellow River Delta, China. Geoderma, 349, 25-35. 
Xu, Z., Shao, T., Lv, Z., Yue, Y., Liu, A., Long, X., ... Rangel, Z. (2020). The mechanisms of improving coastal saline soil by planting rice. Sciene of the Total Environment, 703(135529), $1-11$.

Zhang, W., Chong, W., Rui, X., \& Li-jie, W. (2019). Effect of salinity on the soil microbial community and soil fertility. Journal of Integrative Agriculture, 18(6), 1360-1368. 
Appendix 1. Analysis of variance results in the influence of cropping patterns and application of biological fertilizers

\begin{tabular}{lrrrrr}
\hline Source of variation & $\begin{array}{c}\text { Sum of } \\
\text { squares }\end{array}$ & Df & $\begin{array}{r}\text { Mean } \\
\text { square }\end{array}$ & F Calc. & Sig. \\
\hline $\begin{array}{l}\text { Cropping pattern*biofertilizer } \\
\quad \quad \text { Height }\end{array}$ & 114620.75 & 8 & 14327.59 & 1.99 & 0.050 \\
$\quad$ Diameter & 52.44 & 8 & 6.56 & 1.46 & 0.174 \\
$\begin{array}{l}\text { Cropping pattern } \\
\text { - height }\end{array}$ & 12406.27 & 2 & 6203.14 & 0.16 & 0.856 \\
$\quad$ Diameter & 31.555 & 2 & 15.78 & 0.31 & 0.750 \\
Bio Fertilizer & & & & & \\
$-\quad$ Height & 34433.01 & 4 & 8608.25 & 1.196 & 0.314 \\
$\quad$ Diameter & 68.99 & 4 & 17.25 & 3.84 & $0.005^{*}$ \\
\hline
\end{tabular}

Remarks: *Significant at 95\% confidence level 